JOURNAL OF
PLANT PHYSIOLOGY

www.elsevier.de/jplph

\title{
Does salicylic acid regulate antioxidant defense system, cell death, cadmium uptake and partitioning to acquire cadmium tolerance in rice?
}

\author{
Bin Guo ${ }^{\mathrm{a}, \mathrm{b}}$, Yongchao Liang ${ }^{\mathrm{c}, \mathrm{d}, *}$, Yongguan Zhu ${ }^{\mathrm{e}, * *}$
}

\begin{abstract}
${ }^{a}$ Department of Plant Nutrition, College of Natural Resources and Environmental Sciences, Nanjing Agricultural University, Nanjing 210095, PR China

${ }^{\mathrm{b}}$ Institute of Soil and Fertilizer, Zhejiang Academy of Agricultural Sciences, Hangzhou 310021, PR China

${ }^{\mathrm{C} K e y}$ Laboratory of Oasis Eco-agriculture, College of Agriculture, Shihezi University, Shihezi 832003, PR China

$\mathrm{d}$ Institute of Soil and Fertilizer, Ministry of Agriculture Key Laboratory of Plant Nutrition and Nutrient Cycling, Chinese Academy of Agricultural Sciences, Beijing 100081, PR China

${ }^{\mathrm{e}}$ Research Center for Eco-environmental Sciences, Chinese Academy of Sciences, Beijing 100085, PR China
\end{abstract}

Received 30 September 2007; received in revised form 30 December 2007; accepted 3 January 2008

KEYWORDS

Antioxidant defense

system;

Cadmium;

Rice;

Salicylic acid;

Split-root system

\begin{abstract}
Summary
Salicylic acid (SA) may accelerate the cell death of cadmium-stressed roots to avoid cadmium (Cd) uptake by plants or may play positive roles in protecting the stressed roots from Cd-induced damage. To test these hypotheses, we performed a series of split-root hydroponic experiments with one-half of rice (Oryza sativa L. cv. Jiahua 1) roots exposed to $50 \mu \mathrm{M} \mathrm{Cd}$ and the other half not exposed. The objectives were to elucidate the effects of SA pretreatment on the time-dependent changes of $\mathrm{H}_{2} \mathrm{O}_{2}$ levels in roots, antioxidant defense system in different organs, root cell death and the dynamic distribution of $\mathrm{Cd}$ in the plants. In the split-root system, a higher $\mathrm{Cd}$ uptake rate was observed in the Cd-stressed portions of roots compared with the treatment with the whole roots exposed to Cd. Furthermore, an appreciable amount of $\mathrm{Cd}$ was translocated from the $\mathrm{Cd}$-exposed roots to the unexposed roots and trace amounts of $\mathrm{Cd}$ were released into the external solution. The split-root method also caused the two root portions to respond differently to Cd stress. The activities of major antioxidant enzymes (superoxide dismutase, SOD; peroxidase, POD; and catalase, CAT) were significantly suppressed in the $\mathrm{Cd}$-treated roots, hence leading to $\mathrm{H}_{2} \mathrm{O}_{2}$ burst, lipid peroxidation, cell death and growth inhibition. By contrast, in
\end{abstract}

Abbreviations: CAT, catalase; GSH, glutathione; MDA, malondialdehyde; NPT, non-protein thiols; POD, peroxidase; SA, salicylic acid; SOD, superoxide dismutase.

*Corresponding author at: Key Laboratory of Oasis Eco-agriculture, College of Agriculture, Shihezi University, Shihezi 832003, PR China. Tel./fax: +869932055000.

**Also to be corresponded to.

E-mail addresses: ycliang@caas.ac.cn (Y. Liang), ygzhu@rcees.ac.cn (Y. Zhu). 
the non-Cd-treated roots, the activities of enzymes (SOD, CAT, and POD) and root growth were persistently stimulated during the experimental period. The $\mathrm{H}_{2} \mathrm{O}_{2}$ accumulation and lipid peroxidation were also induced in the non-Cd-treated roots, but they were significantly lower than those of the $\mathrm{Cd}$-treated roots. The concentrations of glutathione (GSH) and non-protein thiols (NPT) in the Cd-treated roots were significantly higher than those of the untreated roots. SA pretreatment elevated enzymatic and non-enzymatic antioxidants, and the concentrations of GSH and NPT in roots and shoots, hence leading to alleviation of the oxidative damage as indicated by the lowered $\mathrm{H}_{2} \mathrm{O}_{2}$ and MDA levels. Furthermore, SA pretreatment mitigated the $\mathrm{Cd}$-induced growth inhibition in both roots and shoots and increased transpiration compared with non-SA-pretreatment under $\mathrm{Cd}$ exposure. It is concluded that $\mathrm{Cd}$ can be partly transferred from the Cd-exposed roots to $\mathrm{Cd}$ unexposed roots and that cell death can be accelerated in the Cd-stressed roots in response to $\mathrm{Cd}$ stress. The SA-enhanced $\mathrm{Cd}$ tolerance in rice can be attributed to SAelevated enzymatic and non-enzymatic antioxidants and NPT, and to SA-regulated Cd uptake, transport and distribution in plant organs.

(c) 2008 Elsevier $\mathrm{GmbH}$. All rights reserved.

\section{Introduction}

Cadmium ( $\mathrm{Cd}$ ) is a ubiquitous element in the environment and is highly toxic to living organisms. In plants, Cd toxicity has been found to interfere with electron transport chains or block antioxidant enzymes structures, leading to accumulation of $\mathrm{H}_{2} \mathrm{O}_{2}$, and oxidative damage (e.g. lipid peroxidation), membrane leakage and finally cell death (Schützendübel et al., 2001; Schützendübel and Polle, 2002).

The $\mathrm{H}_{2} \mathrm{O}_{2}$-triggered cell death has been wellrecognized and is an essential process to maintain tissue or organ homeostasis in concert with cell proliferation, growth, and differentiation (Greenberg, 1996; Mittler et al., 2004). Furthermore, under unfavorable conditions, cell death allows the plant to defend against biotic stress or to obtain more resources by reducing or even stopping growth of plant tissues. For example, $\mathrm{H}_{2} \mathrm{O}_{2}$-induced cell death has been best described during incompatible plant-pathogen interactions that form the basis for the hypersensitive response (HR) (Durner et al., 1997), and aerenchyma formation in root cortex for the toleration of low-oxygen soil environments (Drew et al., 2000). Studies with Nicotiana tabacum (TBY-2) (Fojtová and Kovařík, 2000) and Scots pine (Pinus sylvestris) (Schützendübel et al., 2001) have shown that $\mathrm{Cd}$ induced the morphology of cell death which was related to the $\mathrm{H}_{2} \mathrm{O}_{2}$ burst. However, to our knowledge, there have been no reports to show whether cell death in root tissues can build up a physical barrier to inhibit $\mathrm{Cd}$ uptake, and consequently benefit the whole plant through the avoidance of $\mathrm{Cd}$ toxicity as the mode of plant-pathogen interactions.
Salicylic acid (SA) acts as an important signaling element in plants, which has broad but divergent effects on damage development or stress acclimation of plants (Durner et al., 1997). Upon pathogen attack, SA accumulates to high levels at the site of pathogenic infection, binds and inhibits tobacco CAT activity in vitro and in vivo, thereby leading to an increase in the endogenous level of $\mathrm{H}_{2} \mathrm{O}_{2}$, which could then serve as a second messenger to induce cell death to create a physical barrier against pathogens. However, it is also reported that SA plays a key role in promoting plant resistance to various abiotic stresses. It has previously been reported that SA alleviated growth inhibition by $\mathrm{Cd}$ toxicity in barley (Hordeum vulgare) and soybean (Glycine max) (Metwally et al., 2003; Drazic and Mihailovic, 2005) and in rice (Guo et al., 2007a), although the underlying mechanism is not fully understood. Our more recent studies have shown that pretreatment of rice seeds with SA enhanced the antioxidant defense activities in Cd-stressed rice, thus alleviating $\mathrm{Cd}$-induced oxidative damage and enhancing $\mathrm{Cd}$ tolerance. The possible mechanism involved was thought to be related to SA-induced $\mathrm{H}_{2} \mathrm{O}_{2}$ signaling in mediating $\mathrm{Cd}$ tolerance (Guo et al., 2007a). Thus, it is interesting to elucidate whether (1) SA has negative roles in accelerating partial root death to avoid Cd uptake, in an analog to the mode of action of SA-enhanced plant defense against pathogens through $\mathrm{H}_{2} \mathrm{O}_{2}$ bursts and consequent cell death, or (2) SA plays positive roles in protecting roots from damage in response to $\mathrm{Cd}$ stress. Therefore, we conducted a series of hydroponic experiments using a splitroot system to investigate the time-dependent changes of $\mathrm{H}_{2} \mathrm{O}_{2}$ levels in roots, antioxidant defense 
system in different organs and root cell death under $\mathrm{Cd}$ stress and their relationships with the dynamic distribution of $\mathrm{Cd}$ following pretreatment of SA.

\section{Materials and methods}

\section{Plant materials and experimental design}

Seeds of rice (Oryza stativa L. cv. Jiahua 1) were surface sterilized with $\mathrm{H}_{2} \mathrm{O}_{2}(10 \%)$ for $10 \mathrm{~min}$, rinsed thoroughly with distilled water, and sown in trays. When the second leaf emerged, seedlings of uniform size were transferred to hydroponics pots $(1 \mathrm{~L}, \mathrm{PVC}, 6$ plants per pot) containing nutrient solution (full strength composition: $5 \mathrm{mM} \mathrm{NH} \mathrm{NNO}_{3}, 2 \mathrm{mM} \mathrm{K}_{2} \mathrm{SO}_{4}, 4 \mathrm{mM} \mathrm{CaCl}, 1.6 \mathrm{mM}$ $\mathrm{MgSO}_{4}, 1.2 \mathrm{mM} \mathrm{KH}_{2} \mathrm{PO}_{4}, 50 \mu \mathrm{M} \mathrm{Fe}(\mathrm{II})$-EDTA, $10 \mu \mathrm{M} \mathrm{H}_{3} \mathrm{BO}_{4}$, $1 \mu \mathrm{M} \mathrm{ZnSO}{ }_{4}, 1 \mu \mathrm{M} \mathrm{CuSO}_{4}, 5 \mu \mathrm{M} \mathrm{MnSO}_{4}, 0.5 \mu \mathrm{M} \mathrm{Na}_{2} \mathrm{MoO}_{4}$, and $\left.0.19 \mu \mathrm{M} \mathrm{CoSO}_{4}\right)$. The nutrient solution was adjusted to $\mathrm{pH} 5.5$ daily using $0.1 \mathrm{M} \mathrm{HCl}$ or $\mathrm{NaOH}$, and renewed twice a week. Forty days after the pre-culture, uniform individuals were selected and transferred to split-root pots ( $500 \mathrm{~mL}$, PVC, 1 plant per pot), with a plastic divider embedded in the center. Approximately equal portions of roots were placed in each compartment. The experiment was conducted in a growth chamber with 14-h-photoperiod (8:00-22:00) daily, a photosynthetic photon flux density of $350 \mu \mathrm{mol} \mathrm{m} \mathrm{m}^{-2} \mathrm{~s}^{-1}, 25^{\circ} \mathrm{C} / 18^{\circ} \mathrm{C}$ day/night temperatures, and $70 \%$ relative humidity.

After rice plants had been acclimated in the split-root system for $15 \mathrm{~d}$, four treatments with four replicates each were established (Table 1): i.e. (1) neither SA nor Cd (CK), (2) both halves exposed to $50 \mu \mathrm{M} \mathrm{Cd}(\mathrm{W}+\mathrm{Cd})$, (3) half exposed to $\mathrm{Cd}(+\mathrm{Cd})$ and the other half not exposed $(-C d)$, and (4) pretreatment of all roots with $10 \mu \mathrm{M} \mathrm{SA}$ for $72 \mathrm{~h}$ followed by exposing half of the roots to $\mathrm{Cd}(\mathrm{SA}+\mathrm{Cd})$ and the other half not ( $\mathrm{SA}-\mathrm{Cd})$. Cd was added as cadmium chloride $\left(\mathrm{CdCl}_{2}\right)$. Rice plants from the four replicates per treatment were harvested $0,2,5$ or $10 \mathrm{~d}$ after $\mathrm{Cd}$ treatment. Two separate experiments were performed, one to measure biomass and $\mathrm{Cd}$ concentration, and the other to determine antioxidant enzyme activity and non-enzymatic antioxidants, and cell death. The experiments were duplicated to ensure that the data obtained were reliable.

Table 1. Details of each treatment in the split-root system

\begin{tabular}{|c|c|c|c|c|c|}
\hline \multirow[t]{2}{*}{ Treatment name } & $\mathrm{CK}$ & $W+C d$ & \multicolumn{2}{|c|}{ $\pm C d$} & $\mathrm{SA} \pm \mathrm{Cd}$ \\
\hline & $\mathrm{R}_{\mathrm{L}}^{*} \mathrm{R}_{\mathrm{R}}$ & $\mathrm{R}_{\mathrm{L}} \mathrm{R}$ & $\mathrm{R}+\mathrm{Cd}$ & $-C d$ & $\mathrm{SA}+\mathrm{Cd} \mathrm{SA}-\mathrm{Cd}$ \\
\hline Cd treatr & $-{ }^{\dagger}-$ & ++ & + & - & - \\
\hline SA treatment & $-\quad-$ & - & - & - & + \\
\hline
\end{tabular}

\footnotetext{
${ }^{*} \mathrm{R}_{\mathrm{L}}$ or $\mathrm{R}_{\mathrm{R}}$ indicates root part in left or right compartment in the split root system, respectively.

$\dagger_{-}^{+}$, no Cd or SA treatment and +, Cd or SA treatment.
}

Determination of Cd contents in plant organs and nutrient solutions

After rice plants were sampled, $30 \mathrm{~mL}$ nutrient solution in each root compartment of four treatments was immediately taken out. The roots were immersed in a $5 \mathrm{mM} \mathrm{CdCl}_{2}$ solution for $5 \mathrm{~min}$ to remove the apoplastic $\mathrm{Cd}$, then washed thoroughly with deionized water and dried in an oven at $80^{\circ} \mathrm{C}$ to a constant weight. Plant samples were weighted and ground to pass $0.5 \mathrm{~mm}$ and then digested with a mixture of $\mathrm{HNO}_{3}$ and $\mathrm{HClO}_{4}(10: 1, \mathrm{v} / \mathrm{v})$ at $160{ }^{\circ} \mathrm{C}$ for $30 \mathrm{~h}$. The contents of $\mathrm{Cd}$ in nutrient solutions and digestions were determined by inductively coupled plasma-atomic emission spectroscopy (ICP-AES) (OPTIMA 2000, Perkin-Elmer, USA).

\section{Assays of enzymatic antioxidants in rice roots}

Fresh root samples $(0.5 \mathrm{~g})$ were ground in liquid $\mathrm{N}_{2}$ and homogenized in an ice-bath in $10 \mathrm{~mL}$ homogenizing solution containing $50 \mathrm{mM}$ potassium phosphate buffer and $1 \%(\mathrm{w} / \mathrm{v})$ polyvinylpyrrolidone $(\mathrm{pH} 7.8)$. The homogenate was centrifuged at $8000 \times g$ at $4{ }^{\circ} \mathrm{C}$ for $15 \mathrm{~min}$. The supernatant was stored at $4^{\circ} \mathrm{C}$ for the analysis of the SOD, CAT, and POD activities and soluble protein concentration. The SOD activity was measured by the photochemical method described by Giannopolitis and Ries (1977). One unit SOD activity was defined as the amount of enzyme required to result in a $50 \%$ inhibition of the rate of NBT ( $\rho$-nitro blue tetrazolium chloride) reduction measured at $560 \mathrm{~nm}$. The POD activity was assayed following the method of Beffa et al. (1990). Changes in the absorbance of the brown guaiacol at $460 \mathrm{~nm}$ in the presence of $\mathrm{H}_{2} \mathrm{O}_{2}$ were recorded for calculating POD activity. The CAT activity was assayed using the method described by Aebi (1984). The activity was assayed by monitoring the decrease in the absorbance at $240 \mathrm{~nm}$ as a consequence of $\mathrm{H}_{2} \mathrm{O}_{2}$ consumption. The enzyme activity was expressed as units $\left(\mu \mathrm{M}\right.$ of $\mathrm{H}_{2} \mathrm{O}_{2}$ decomposed per minute) per $\mathrm{mg}$ of protein. Soluble protein concentration was analyzed according to Bradford (1976), using Coomassie Brilliant Blue G-250 (Sigma) as dye and albumin (Bovine V; Sigma) as a standard.

\section{Assays of GSH concentrations in rice roots and shoots}

Total glutathione (GSH) was determined according to Hissin and Hilf (1976). Fresh samples were ground with a homogenizing solution containing $25 \% \mathrm{H}_{3} \mathrm{PO}_{3}$ and $0.1 \mathrm{M}$ sodium phosphate-EDTA buffer $(\mathrm{pH} \mathrm{8.0)}$. The homogenate was centrifuged at $10,000 \times g$ for $20 \mathrm{~min}$. The final assay mixture contained supernatant, phosphate-EDTA buffer and $O$-phthalaldehyde $\left(1 \mathrm{mg} \mathrm{mL}^{-1}\right)$. The solution was measured fluorimetrically at $420 \mathrm{~nm}$ after excitation at $350 \mathrm{~nm}$.

\section{Assay of concentration of NPT in rice roots and shoots}

The concentration of non-protein thiols (NPT) was determined by measuring the absorbance at $412 \mathrm{~nm}$ 
following the method of Metwally et al. (2003). For this, $0.5 \mathrm{~g}$ of fresh root segments were homogenized in an ice-bath in $5 \mathrm{~mL}$ of potassium phosphate buffer $(\mathrm{pH} 8.0)$, and the homogenate was centrifuged at $10,000 \times g$ for $20 \mathrm{~min}$. The supernatant was used for NPT assay using 5,5-dithio-2,2-dinitrobenzoic acid as a reagent.

\section{Assay of concentration of MDA in rice roots}

Root tissues $(500 \mathrm{mg}$ ) were homogenized in $3 \mathrm{~mL} 0.1 \%$ trichloroacetic acid (TCA) solution. The homogenate was centrifuged at $2500 \times g$ for $10 \mathrm{~min}$ and the supernatant was assayed for malondialdehyde (MDA) concentration with thiobarbituic acid (TBA) test using the method given by Heath and Packer (1968).

\section{Assay of concentration of $\mathrm{H}_{2} \mathrm{O}_{2}$ in rice roots}

The concentration of $\mathrm{H}_{2} \mathrm{O}_{2}$ was determined using the method of Brennan and Frenkel (1977). Fresh roots (2g) were homogenized in refrigerated acetone $(10 \mathrm{~mL})$ and centrifuged at $10,000 \times g$ for $10 \mathrm{~min}$. One milliliter of the supernatant was mixed with $0.1 \mathrm{~mL} 5 \% \mathrm{Ti}\left(\mathrm{SO}_{4}\right)_{2}$ and $0.2 \mathrm{~mL}$ ammonia. After the precipitate was formed, the reaction mixture was centrifuged at $10,000 \times g$ for 10 min. The resulting pellet was dissolved in $2 \mathrm{M} \mathrm{H}_{2} \mathrm{SO}_{4}$ and the absorbance was measured at $415 \mathrm{~nm}$. The $\mathrm{H}_{2} \mathrm{O}_{2}$ level was calculated according to a standard curve of $\mathrm{H}_{2} \mathrm{O}_{2}$.

\section{Measurement of cell death}

Cell death was measured according to the method described by Schützendübel et al. (2001). After Cd or SA treatment, three root tips $(2 \mathrm{~cm})$ were incubated in Evans blue solution $(0.025 \%(\mathrm{w} / \mathrm{v})$ Evans blue in water) for $30 \mathrm{~min}$, followed by washing with water for $15 \mathrm{~min}$. The trapped Evans blue was released from the roots by homogenizing root tips with a microhomogenizer in $1.6 \mathrm{~mL}$ of a measuring solution (50\% (v/v) MeOH and $1 \%$ $(\mathrm{w} / \mathrm{v}) \mathrm{SDS})$. The homogenate was incubated for $15 \mathrm{~min}$ in a water bath at $50{ }^{\circ} \mathrm{C}$ and centrifuged at $10,000 \times g$ for $15 \mathrm{~min}$. The optical density of the supernatant was determined at $600 \mathrm{~nm}$ and expressed on the basis of fresh weight.

\section{Measurement of transpiration}

Whole-shoot transpiration in different treatments was calculated by measuring the heights of water levels at the beginning and the end of the experiments. The volumes of water loss were calculated by using the heights of water levels and the bottom area of the cylinder pots. In all cases, evaporation from the pots was minimized by covering the exposed surface with a layer of PVC.

\section{Statistical analysis}

SPSS software (SPSS Inc., 2000) was used for data analysis. All data were expressed as means \pm S.D. and the means were subjected to test of statistical significance using Duncan's method at the $5 \%$ probability level.

\section{Results}

\section{Effects of SA and Cd on plant growth and Cd distribution in rice in the split-root system}

On Day 2, plant biomass did not differ among treatments (Figure 1). On Day 5, Cd addition significantly decreased the root dry weight in the + Cd compartment, while pretreatment with SA produced no effect $(P<0.05)$ (Figure 1). On Day 10, root dry weight of the $+\mathrm{Cd}$ compartment was $35.3 \%$ less than that of the $\mathrm{W}+\mathrm{Cd}$ compartment (Figure 1). By contrast, root dry weight of the - Cd compartment was $25.0 \%$ higher than the control. SA pretreatment with $\mathrm{Cd}$ exposure $(\mathrm{SA}+\mathrm{Cd})$ significantly increased root dry weight by $36.4 \%$ compared to the $+\mathrm{Cd}$ compartment alone. Shoot growth was decreased in the $\mathrm{W}+\mathrm{Cd}$ and $-\mathrm{Cd}$ treatments on Day 5 and Day 10. SA treatment significantly alleviated the inhibitory effect of $\mathrm{Cd}$ on shoot growth compared with the $\mathrm{Cd}$ treatment alone (Figure 1).

Cd concentration in roots of the $+\mathrm{Cd}$ compartment was significantly higher than that of the $\mathrm{W}+\mathrm{Cd}$ compartment on Day 5 and Day 10, whereas the reverse was true for shoots on Day 10 (Figure 1). The time-dependent increase in $\mathrm{Cd}$ was also found in the -Cd compartment, although this portion of the roots was not exposed to $\mathrm{Cd}$ directly. For example, $\mathrm{Cd}$ concentration in roots of the -Cd compartment was 1.5-fold higher on Day 10 than on Day 2 (Figure 1). By contrast, no time-dependent change in $\mathrm{Cd}$ concentration was observed in the $+\mathrm{Cd}$ compartment. The $\mathrm{Cd}$ concentration was significantly higher in the SA-Cd compartment than in the - Cd compartment. For example, $\mathrm{Cd}$ concentration in the SA-Cd compartment increased by $25 \%$ and $28 \%$ on Day 5 and Day 10, respectively, compared with the $-\mathrm{Cd}$ compartment (Figure 1). Specific $\mathrm{Cd}$ uptake expressed as total amounts of $\mathrm{Cd}$ in whole plant on a basis of dry weights of roots exposed to $\mathrm{Cd}$ in the $+\mathrm{Cd}$ and $\mathrm{SA}+\mathrm{Cd}$ compartments was about twofold higher than in the $\mathrm{W}+\mathrm{Cd}$ compartment from Day 5 (Figure 2), showing higher $\mathrm{Cd}$ uptake by roots in the $+\mathrm{Cd}$ compartment than in the $\mathrm{W}+\mathrm{Cd}$ compartment. 

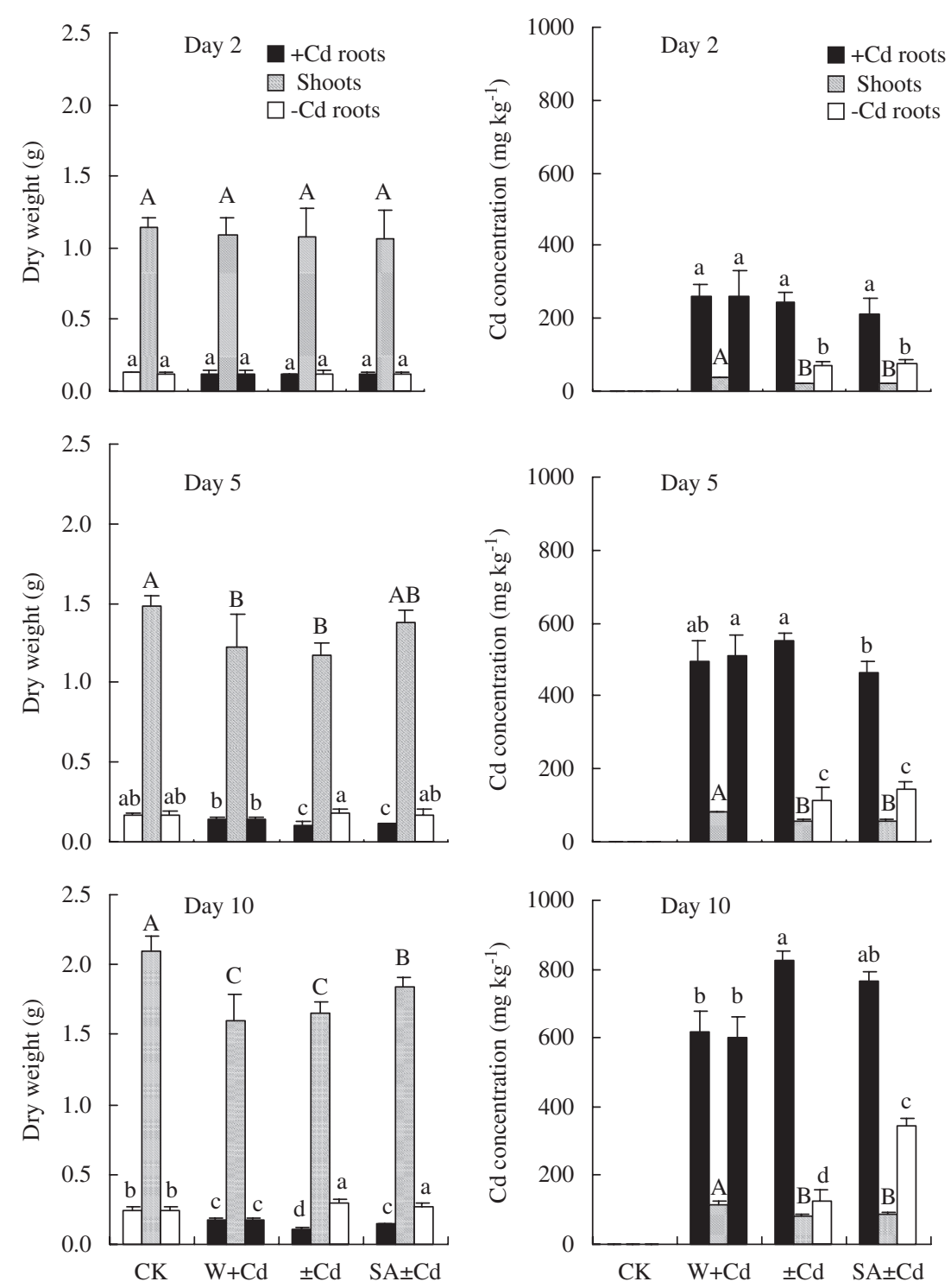

Figure 1. Shoot and root dry weight (g) and Cd concentration of rice (expressed on a dry weight basis) pretreated with $10 \mu \mathrm{M} \mathrm{SA}$ or exposed to $50 \mu \mathrm{M} \mathrm{Cd}$ in a split-root system. Means of $n=4 \pm$ S.D. Different letters above bars mean significance of differences in shoots (capitals) and roots (lower case) between any two treatments $(P<0.05$, ANOVA; according to Duncan's multiple range test). CK: neither SA pretreatment nor Cd treatment; $W+C d$ : both portions of the root system exposed to $50 \mu \mathrm{M}$ cadmium; $\pm C \mathrm{Cd}$ : half of the roots exposed to cadmium $(+C d)$ and the other half not exposed $(-C d) ; S A \pm C d$ : half of the roots exposed to cadmium $(S A+C d)$ and the other half not exposed $(S A-C d)$ following pretreatment of all roots with $10 \mu \mathrm{M} \mathrm{SA}$ for $72 \mathrm{~h}$.

Water loss from the nutrient solutions, used as a measure of transpiration, is shown in Figure 3A. Depletion of $\mathrm{Cd}$ in the nutrient solution was more pronounced in the $+\mathrm{Cd}$ and $\mathrm{SA}+\mathrm{Cd}$ compartments than in the $\mathrm{W}+\mathrm{Cd}$ compartment, showing higher $\mathrm{Cd}$ uptake by roots in the $+\mathrm{Cd}$ compartment than in the $\mathrm{W}+\mathrm{Cd}$ compartment (Figure 3B). The fact that $\mathrm{Cd}$ was detectable in the solutions of the $-\mathrm{Cd}$ and $\mathrm{SA}-\mathrm{Cd}$ compartments (Figure 3B) showed that $\mathrm{Cd}$ was released into the solutions from the roots grown in the non-Cd-amended compartments.

\section{Effect of SA and $\mathrm{Cd}$ on $\mathrm{H}_{2} \mathrm{O}_{2}$ levels and antioxidant system of rice root in the split-root system}

Cd exposure increased $\mathrm{H}_{2} \mathrm{O}_{2}$ levels in roots from Day 2 to Day 5, and $\mathrm{H}_{2} \mathrm{O}_{2}$ tended to decline on Day 10 in all $+\mathrm{Cd}$ treatments (Figure $4 \mathrm{~A}$ ). The addition 
of $\mathrm{Cd}$ to the $+\mathrm{Cd}$ compartment induced the highest $\mathrm{H}_{2} \mathrm{O}_{2}$ concentration in the $\mathrm{Cd}$-exposed roots during the experimental period. The increments in $\mathrm{H}_{2} \mathrm{O}_{2}$ levels were also observed in the roots grown in the -Cd compartment, but were significantly lower than those in the $+\mathrm{Cd}$ compartment. Pretreatment with SA prior to $\mathrm{Cd}$ addition increased $\mathrm{H}_{2} \mathrm{O}_{2}$ concentrations in roots compared with the control. However, after $\mathrm{Cd}$ exposure, $\mathrm{SA}$ pretreatment decreased the $\mathrm{H}_{2} \mathrm{O}_{2}$ accumulation in the roots grown in the $\mathrm{SA}+\mathrm{Cd}$ compartment compared with the $+C d$ compartment.

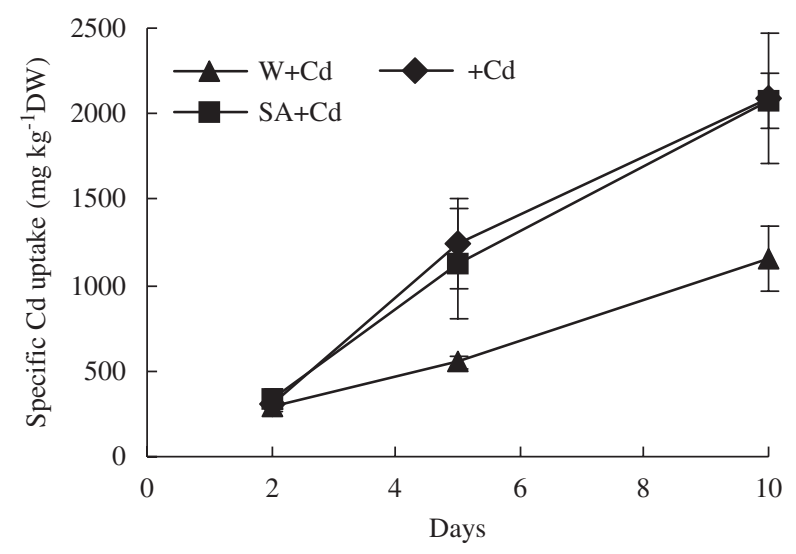

Figure 2. Effect of SA and split-root mode on specific Cd uptake by rice plants in hydroponic solutions. Specific $\mathrm{Cd}$ uptake was calculated as total amounts of $\mathrm{Cd}$ in whole rice divided by dry weights of roots exposed to $\mathrm{Cd}$. Data are expressed as means \pm S.D. $(n=4) . W+C d$ : both portions of the root system exposed to $50 \mu \mathrm{M}$ cadmium; $+\mathrm{Cd}$ : half of the roots exposed to cadmium; $\mathrm{SA}+\mathrm{Cd}$ : half of the roots exposed to cadmium following pretreatment of all roots with $10 \mu \mathrm{M} \mathrm{SA}$ for $72 \mathrm{~h}$.

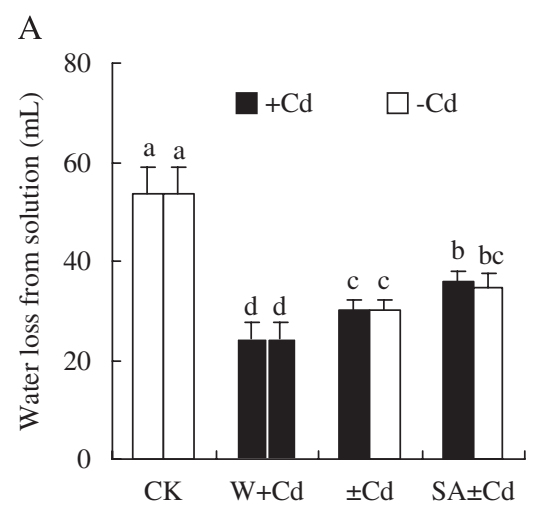

Cd significantly increased the MDA levels in roots compared with the control in the order of $+\mathrm{Cd}>$ $\mathrm{W}+\mathrm{Cd}>\mathrm{SA}+\mathrm{Cd}$ compartment during the experimental period (Figure 4B). Although the increments in MDA concentration in the roots grown in the $-\mathrm{Cd}$ and SA-Cd compartment were also found during the $\mathrm{Cd}$-exposure period, they were all significantly lower compared with the $+\mathrm{Cd}$ compartment.

Cd initially increased SOD and POD activities in roots grown in the $\mathrm{W}+\mathrm{Cd},+\mathrm{Cd}$ and $\mathrm{SA}+\mathrm{Cd}$ compartments on Day 2 (Figure 5A and B). However, this response diminished on Day 5, and was significantly lower than those in the control on Day 10, except for POD in the SA+Cd compartment. In the $-\mathrm{Cd}$ and SA-Cd compartments, root SOD activity increased initially but fell at the later stage, whereas POD activity increased consistently during the whole experimental duration.

Cd exposure decreased CAT activities of roots grown in the $\mathrm{W}+\mathrm{Cd}$ and $+\mathrm{Cd}$ compartments during the experimental period (Figure $5 \mathrm{C}$ ). Pretreatment with SA initially decreased the activity by $47 \%$ prior to $\mathrm{Cd}$ treatment. Exposure to $\mathrm{Cd}$ increased CAT activity by $61 \%$ in the SA+Cd on Day 2 , compared with the control. The activity of CAT in the roots grown in the $\mathrm{SA}+\mathrm{Cd}$ compartment declined rapidly and dropped below the level of control on Day 10. In the - Cd and SA-Cd compartments, the enzyme activity was always higher than the control throughout the Cd-exposure period.

SA pretreatment initially increased GSH concentration in roots by $57 \%$ prior to $\mathrm{Cd}$ treatment (Figure 6A). By contrast, Cd exposure strongly decreased GSH concentration on Day 2, compared with the control (Figure 6A). A recovery of GSH level occurred in the $\mathrm{W}+\mathrm{Cd},+\mathrm{Cd}$ and $\mathrm{SA}+\mathrm{Cd}$

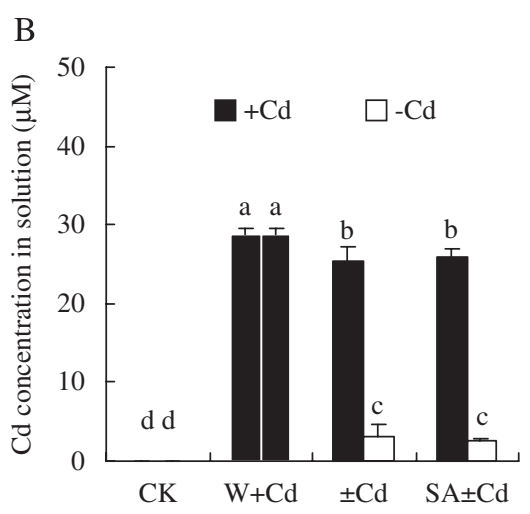

Figure 3. Transpiration measured as water loss in solution $(A)$ and $C d$ concentration $(B)$ in the two compartments after 48-h-exposure of $50 \mu \mathrm{M} \mathrm{Cd}$ in different treatments. Data are expressed as means \pm S.D. $(n=4)$. Different letters above the bars mean significance of difference between any two treatments $(P<0.05$, ANOVA; according to Duncan's multiple range test). CK: neither SA pretreatment nor Cd treatment in the split-root system; W+Cd: both portions of root system exposed to $50 \mu \mathrm{M}$ cadmium; $\pm \mathrm{Cd}$ : half of the roots exposed to cadmium $(+\mathrm{Cd})$ and the other half not exposed $(-\mathrm{Cd})$; $\mathrm{SA} \pm \mathrm{Cd}$ : half of the roots exposed to cadmium $(\mathrm{SA}+\mathrm{Cd})$ and the other half not exposed $(\mathrm{SA}-\mathrm{Cd})$ following pretreatment of all roots with $10 \mu \mathrm{M}$ SA for $72 \mathrm{~h}$. 
compartments on Day 5. However, GSH concentration of roots grown in the $+\mathrm{Cd}$ compartment dropped again to $25 \%$ lower than the control on Day 10. In shoots, time-dependent increases in GSH concentration were found in all the $\mathrm{Cd}$ treatments regardless of SA pretreatment throughout the experimental period (Figure 6B). The addition of Cd consistently increased NPT levels in roots in all treatments except the control (Figure 6C). NPT level in roots was initially stimulated by the SA pretreatment, and then further enhanced by the subsequent $\mathrm{Cd}$ exposure, which was 1.9and 2.1-fold higher on Day 5 and Day 10, respectively, compared with the control. NPT concentration was highest in the shoots grown in the $\mathrm{SA} \pm \mathrm{Cd}$
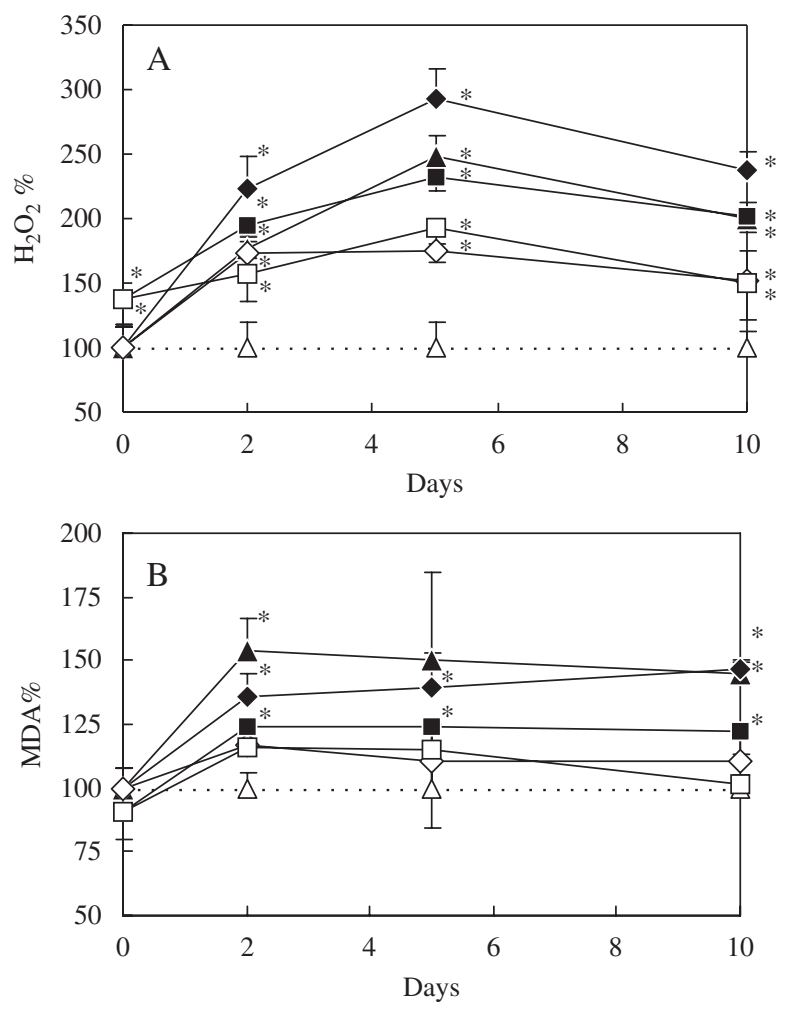

Figure 4. $\mathrm{H}_{2} \mathrm{O}_{2}(\mathrm{~A})$ and MDA $(\mathrm{B})$ concentrations in roots pretreated with $10 \mu \mathrm{M}$ SA or treated with $50 \mu \mathrm{M} \mathrm{Cd}$. The concentrations were expressed relative to the concentration in control plants $(=100 \%$, dashed line). Each value is the mean of four individual replicates ( \pm S.D.). Asterisks indicate values that differ significantly from the control at $P<0.05$ (ANOVA; according to Duncan's multiple range test). Root portions harvested were: neither SA pretreatment nor $\mathrm{Cd}$ treatment in the split-root system $(\Delta, C K)$; both portions exposed to $50 \mu \mathrm{M}$ cadmium $(\boldsymbol{\Delta}$, $\mathrm{W}+\mathrm{Cd})$; half of the roots exposed to cadmium $(\bullet,+\mathrm{Cd})$ and the other half not exposed $(\diamond,-C d)$; half of the roots exposed to cadmium ( $\mathbf{\square}, \mathrm{SA}+\mathrm{Cd}$ ) and the other half not exposed $(\square, S A-C d)$ following pretreatment of all roots with $10 \mu \mathrm{M}$ SA for $72 \mathrm{~h}$. treatment, followed by the $\mathrm{W}+\mathrm{Cd}$ and $\pm \mathrm{Cd}$ treatments throughout the experimental period (Figure 6D).
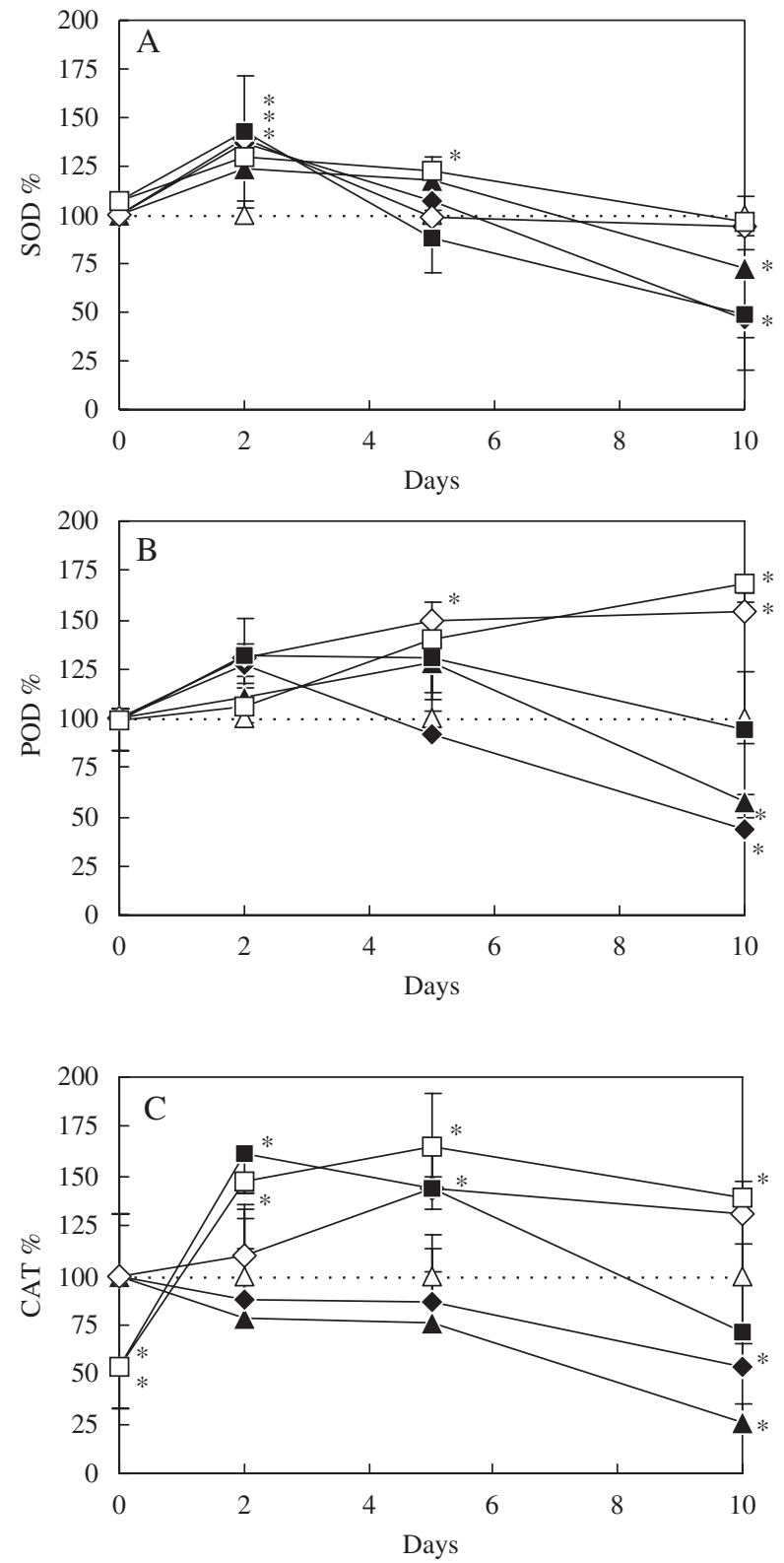

Figure 5. SOD (A), POD (B) and CAT (C) activities in roots pretreated with $10 \mu \mathrm{M}$ SA or treated with $50 \mu \mathrm{M} \mathrm{Cd}$. The activities were expressed relative to the activities in control plants ( $=100 \%$, dashed line). Each value is the mean of four individual replicates $( \pm$ S.D.). Asterisks indicate values that differ significantly from the control at $P<0.05$ (ANOVA; according to Duncan's multiple range test). Root portions harvested were: neither SA pretreatment nor Cd treatment in the split-root system $(\Delta, \mathrm{CK})$; both portions of the roots exposed to $50 \mu \mathrm{M}$ cadmium $(\boldsymbol{\Delta}, \mathrm{W}+\mathrm{Cd})$; half of the roots exposed to cadmium $(\bullet,+C d)$ and the other half not exposed $(\diamond,-C d)$; half of the roots exposed to cadmium $(\boldsymbol{\square}, \mathrm{SA}+\mathrm{Cd})$ and the other half not exposed $(\square, \mathrm{SA}-\mathrm{Cd})$ following pretreatment of all roots with $10 \mu \mathrm{M}$ SA for $72 \mathrm{~h}$. 


\section{Effect of SA and Cd on cell death of roots in the split-root system}

Cell death in root parts was induced upon $\mathrm{Cd}$ exposure during the experimental period (Figure 7A
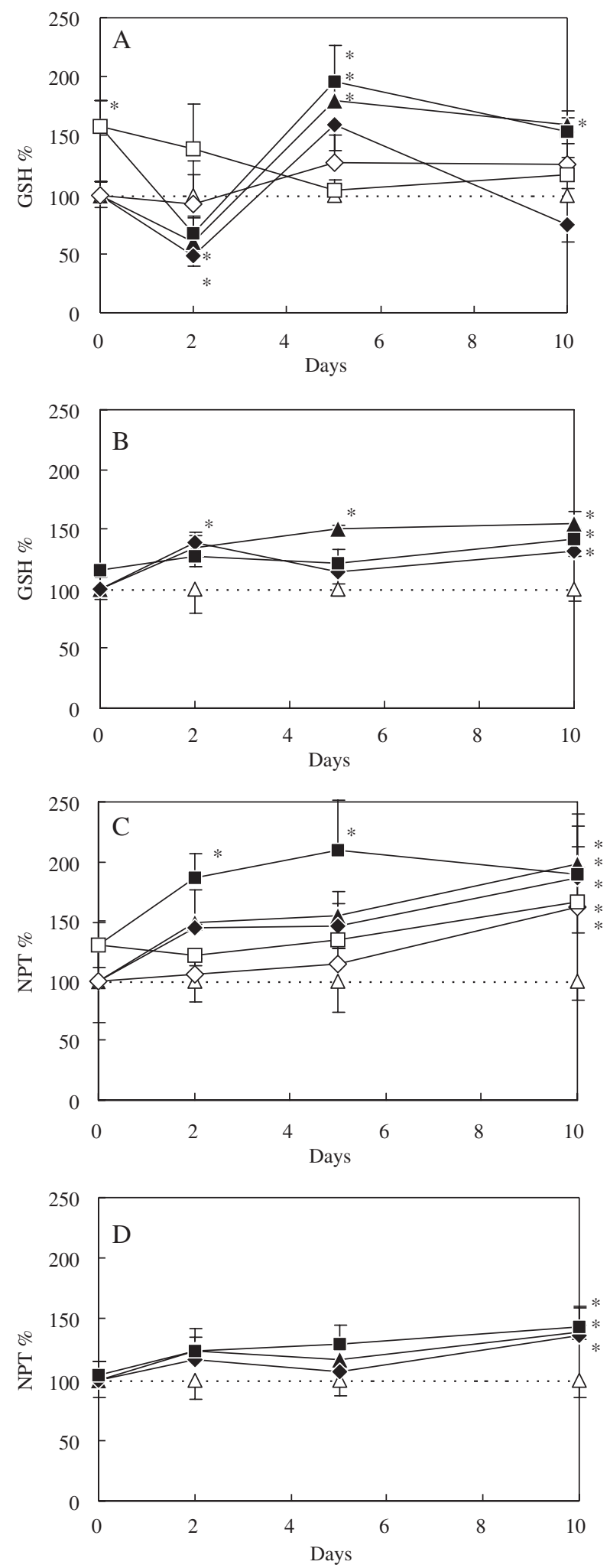

and B). The percentage of uptake of Evans dye reached a plateau after $2 \mathrm{~d}$. There were no significant differences in cell death within 2, 5 and $10 \mathrm{~d}$ for $+\mathrm{Cd}$ and $\mathrm{SA}+\mathrm{Cd}$ treatments. Cell death caused by $\mathrm{Cd}$ was more pronounced in the $+\mathrm{Cd}$ and $\mathrm{SA}+\mathrm{Cd}$ compartments compared with the $\mathrm{W}+\mathrm{Cd}$ compartment on Day $2(P<0.05)$. SA pretreatment had no significant effect on cell death under partial Cd stress.

\section{Discussion}

\section{Cell death, plant growth and Cd transference in the split-root system subjected to $\mathrm{Cd}$ stress}

More growth inhibition (Figure 1) and root cell death (Figure 7B) were observed in the $+\mathrm{Cd}$ compartment than in the $\mathrm{W}+\mathrm{Cd}$ compartment under the same $\mathrm{Cd}$ stress $(50 \mu \mathrm{M})$ in the split-root system $(P<0.05)$. This suggests that there may be an adaptation mechanism by which the plant roots grown in the Cd-stressed compartment were selfsacrificed, hence protecting the whole rice plant from avoiding excessive Cd uptake and toxicity. Surprisingly, Cd concentration (Figure 1), Cd specific uptake (Figure 2) and $\mathrm{Cd}$ depletion in the nutrient solution (Figure $3 \mathrm{~A}$ ) were higher in the $+\mathrm{Cd}$ compartment than in the $\mathrm{W}+\mathrm{Cd}$ compartment $(P<0.05)$.

Cd-induced cell death with rigid lignification in root cell wall has been reported in Scots pine (Schützendübel et al., 2001) and rice (Guo et al., 2007a). Immobilization of Cd in cell wall is one of important mechanisms of $\mathrm{Cd}$ resistance in plants, as our previous study with rice roots showed that $\mathrm{Cd}$ concentration in cell wall was 5.4-fold higher than

Figure 6. GSH (A and $\mathrm{B})$ and NPT (C and $\mathrm{D})$ concentrations in roots and shoots pretreated with $10 \mu \mathrm{M}$ SA or treated with $50 \mu \mathrm{M} \mathrm{Cd}$. The concentrations were expressed relative to the concentration in control plants ( $=100 \%$, dashed line). Each value is the mean of four individual replicates $( \pm$ S.D.). Asterisks indicate values that differ significantly from the control at $P<0.05$ (ANOVA; according to Duncan's multiple range test). Root portions harvested were: neither SA pretreatment nor Cd treatment in the split-root system $(\Delta, \mathrm{CK})$; both portions of the roots exposed to $50 \mu M$ cadmium $(\boldsymbol{\Delta}, W+C d)$; half of the roots exposed to cadmium $(\diamond,+C d)$ and the other half not exposed $(\diamond,-C d)$; half of the roots exposed to cadmium ( $\boldsymbol{\square}, \mathrm{SA}+\mathrm{Cd})$ and the other half not exposed $(\square$, SA-Cd) following pretreatment of all roots with $10 \mu \mathrm{M} \mathrm{SA}$ for $72 \mathrm{~h}$. 

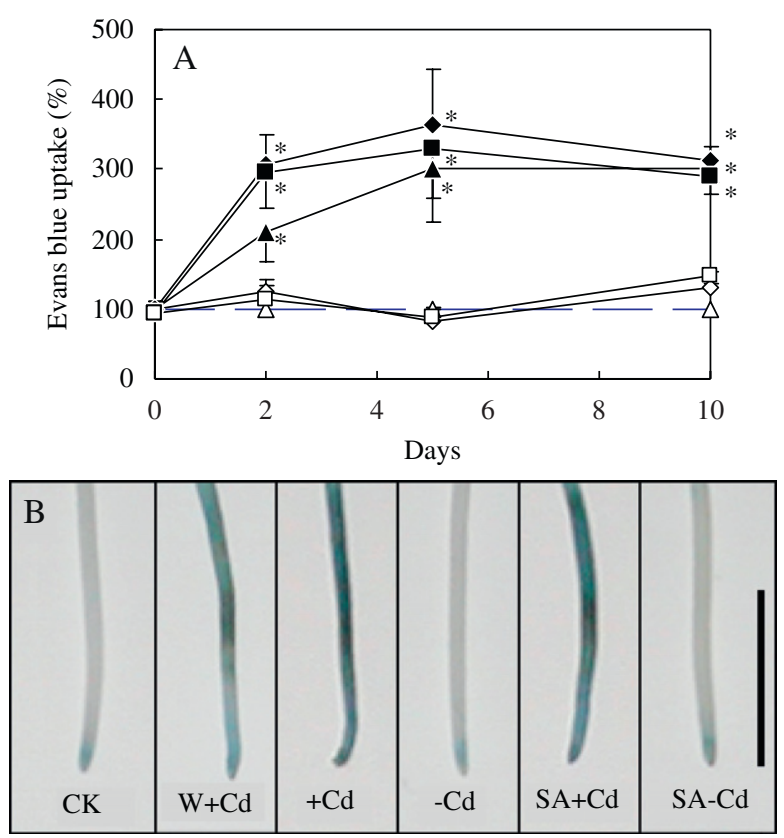

Figure 7. Cell death indicated as Evans blue staining of rice root tips (A) and the picture taken on Day 5 (B); bar $=1 \mathrm{~cm}$. Sections $(1.5 \mathrm{~cm})$ of rice roots were subjected to Evans blue solution $(0.025 \%(\mathrm{w} / \mathrm{v})$ Evans blue in water) to detect cell death (visualized as blue colour). Asterisks indicate values that differ significantly from the control at $P<0.05$ (ANOVA; according to Duncan's multiple range test). All root sections received identical treatment before photography, and all are represented at identical magnification. Root portions harvested were: neither SA pretreatment nor Cd treatment in the splitroot system $(\Delta, C K)$; both portions of roots exposed to $50 \mu \mathrm{M}$ cadmium $(\boldsymbol{\Delta}, \mathrm{W}+\mathrm{Cd})$; half of the roots exposed to cadmium $(\diamond,+C d)$ and the other half not exposed $(\diamond$, $-C d)$; half of the roots exposed to cadmium $(\boldsymbol{\square}, \mathrm{SA}+\mathrm{Cd})$ and the other half not exposed $(\square, S A-C d)$ following pretreatment of all roots with $10 \mu \mathrm{M}$ SA for $72 \mathrm{~h}$. Each value is the mean of three individual replicates $( \pm$ S.D.) and was expressed relative to controls.

in the soluble fraction of cells (Guo et al., 2007b). In the present study, more root cell death in $+\mathrm{Cd}$ compartment (Figure. 7) might be due to higher $\mathrm{Cd}$ retention in this root part than in the $\mathrm{W}+\mathrm{Cd}$ compartment (see Figure 1, Day 5 and Day 10). However, in fact, the Cd-immobilization in rice root may be a defense mechanism that plays a limiting role in $\mathrm{Cd}$ tolerance. As the $\mathrm{Cd}$ stress experiment continued, more $\mathrm{Cd}$ entered into the rice roots and was further transferred into the shoots due to its "saturation effect" (Figure 1). A further question then arises as to why $\mathrm{Cd}$ specific uptake (Figure 2) and $\mathrm{Cd}$ depletion in the nutrient solution (Figure $3 \mathrm{~A}$ ) were higher in the +Cd compartment than in the $\mathrm{W}+\mathrm{Cd}$ compartment $(P<0.05)$. A previous study with Indian mustard showed that $\mathrm{Cd}$ accumulation in shoots was strongly influenced by transpiration (Salt et al., 1995). Generally, transpiration is the most important mechanism for the uptake of nutrient elements (Novák and Vidovič, 2003; Tani and Barrington, 2005; Liao et al., 2006) by its gradient of water potential, which can drive them to move into roots and upward to shoots. This mechanism could be applicable to the Cd uptake pattern in the present study where more water loss from solution (Figure $3 \mathrm{~A}$ ) along with lower $\mathrm{Cd}$ concentration in the solution (Figure $3 \mathrm{~B}$ ) was observed in the $+\mathrm{Cd}$ compartment than in the $\mathrm{W}+\mathrm{Cd}$ compartment during the $36-\mathrm{h}-\mathrm{Cd}$ exposure period. Since $\mathrm{Cd}$ has been shown to strongly inhibit transpiration of plants (Perfus-Barbeoch et al., 2002), the higher transpiration in the $+\mathrm{Cd}$ treatment (Figure $3 \mathrm{~A}$ ) might be accounted for by less $\mathrm{Cd}$ accumulation in the shoots (Figure 1) compared with the $\mathrm{W}+\mathrm{Cd}$ compartment.

An important result of the present study was that considerable amounts of $\mathrm{Cd}$ were re-translocated downward from shoots to the Cd-unexposed roots via phloem (Figure 1), which was also previously reported in wheat (Welch et al., 1999; Page and Feller, 2005). There are two possible mechanisms for this redistribution: (1) Cd is loaded from the xylem sap into phloem sap during the acropetal Cd transportation and (2) Cd stored in shoots is re-translocated into roots together with photosynthate, as with some micronutrients (such as Cu and Zn) (Marschner, 1995). Studies with Indian mustard suggested that Cd transport in the xylem sap was coordinated predominantly with oxygen or nitrogen ligands (Salt et al., 1995). The phloem sap contains various types of ligands, such as metal-binding proteins, nicotianamine and citrate, facilitating the transport of micronutrient cations from source to sink organs (Welch 1995). However, to our knowledge, the process of $\mathrm{Cd}$ loading from xylem sap into phloem sap and the components with $\mathrm{Cd}$ in phloem have not yet been determined and need further investigating.

Interestingly, some $\mathrm{Cd}$ in plants was released from the roots grown in the - $\mathrm{Cd}$ compartment into the external solution (Figure $3 \mathrm{~B}$ ). One possible explanation for the $\mathrm{Cd}$ secretion might be ascribed to the exudation by the cells themselves as has been reported in Lupinus albus (Costa and Morel, 1983). There was some evidence that such exudation in Thlaspi caerulescens was mediated by TcHMA4, a Thlaspi heavy metal ATPase, which is involved in active efflux of a number of heavy metals (Papoyan and Kochian, 2004). Another hypothesis about $\mathrm{Cd}$ release is that the $\mathrm{Cd}$ is 
derived from the decomposed root epidermis of plants, as some evidence has shown that $\mathrm{Cd}$ was principally stored in epidermal cells (Chardonnens et al., 1999; Cosio et al., 2005).

The root growth in the -Cd compartment was significantly stimulated (Figure 1). The mechanism of stimulating plant growth by low, sub-lethal concentrations of heavy metals has not been wellelucidated (Schützendübel et al., 2002). It is hypothesized that the $\mathrm{H}_{2} \mathrm{O}_{2}$ accumulation in the roots grown in the $-\mathrm{Cd}$ compartment might act as a signal in regulating root growth (Figure $1 \mathrm{~A}$ ) by involving cellular redox control and by mediating direct cross-linking of functional groups in the cell walls (Brisson et al., 1994; Foreman et al., 2003).

\section{Different organs in rice plants responded to Cd-induced oxidative stress differently in the split-root system}

Cadmium is known to induce oxidative damage to higher plants (Schützendübel and Polle, 2002). In the present study, the split-root method caused the roots to respond to $\mathrm{Cd}$ stress differently in terms of $\mathrm{H}_{2} \mathrm{O}_{2}$ accumulation (Figure $4 \mathrm{~A}$ ), lipid-peroxidation (Figure 4B) and cell death (Figure 7A and $B$ ) between the plants with or without $\mathrm{Cd}$ treatment. In the $+\mathrm{Cd}$ treatments, the initially increased activities of SOD and POD (Figure $5 \mathrm{~A}$ and $\mathrm{B}$ ) cooperatively controlled the $\mathrm{Cd}$-induced $\mathrm{H}_{2} \mathrm{O}_{2}$ at high homeostatic levels (Figure 4A) during the 2-day-Cd-exposure. However, sustained $\mathrm{Cd}$ stress resulted in decreased activities of antioxidant enzymes (Figure 5A, B and C), possibly due to the binding of $\mathrm{Cd}$ to the thiol groups of enzyme proteins. Thus, the high homeostatic balance of $\mathrm{H}_{2} \mathrm{O}_{2}$ was broken eventually, causing a $\mathrm{H}_{2} \mathrm{O}_{2}$ burst on about Day 5 (Figure 4A). The lower $\mathrm{H}_{2} \mathrm{O}_{2}$ levels at the later stage might be due to more cell death of these roots. However, $\mathrm{H}_{2} \mathrm{O}_{2}$ levels in the $-\mathrm{Cd}$ treatments also increased during the experimental period but much less than those in the $+\mathrm{Cd}$ treatments (Figure 4A), which might be induced by the $\mathrm{Cd}$ translocated from the shoots via phloem (Figure 1). Persistent enhancement of activities of SOD, POD and CAT showed that these root portions maintained the antioxidant defense activity to control $\mathrm{Cd}$-induced $\mathrm{H}_{2} \mathrm{O}_{2}$ level during the experimental period.

Both GSH and NPT are important antioxidant molecules for $\mathrm{Cd}$ detoxification by forming $\mathrm{Cd}$ bindings with their high affinity for SH groups (Lee et al., 2003; Pietrini et al., 2003). Cd initially depleted root GSH levels in the + Cd compartment for the first $2 \mathrm{~d}$ (Figure 6A), which is a common response to $\mathrm{Cd}$ stress in plants as a result of the synthesis of phytochelatins (Schützendübel and Polle, 2002). As the experiment continued, the GSH levels in the $+\mathrm{Cd}$ compartment recovered (Figure $6 \mathrm{~A}$ ), while in the $-\mathrm{Cd}$ treatments, GSH maintained higher levels and exceeded the control levels throughout the experiment. NPT was higher in the $+\mathrm{Cd}$ compartment than in the -Cd compartment with increasing Cd-exposure time (Figure $6 \mathrm{C}$ and $\mathrm{D}$ ).

\section{SA-elevated enzymatic and non-enzymatic antioxidants contributed to alleviation of Cd toxicity in rice}

Pretreatment with SA significantly alleviated the growth inhibition (Figure 1) and transpiration suppression (Figure $3 \mathrm{~A}$ ) caused by Cd stress. Such SA-mitigated Cd toxicity has been shown in other plant species, including barley (Metwally et al., 2003), soybean (Drazic and Mihailovic, 2005) and rice (Guo et al., 2007a), although the underlying mechanism is not fully understood. SA acts as an important signal involved in strengthening cell walls during the process of cell death in plantpathogen interactions (Durner et al., 1997). However, the increase in Cd influx in the present study (Figure 1) ruled out the mechanism of immobilization of Cd by SA-induced reinforcement of cell wall. Furthermore, SA pretreatment did not further induce cell death of $\mathrm{Cd}$-stressed roots (Figure 7).

In the present study, the effect of increase in transpiration by SA pretreatment under Cd stress is consistent with previous studies on SA-induced reversal of inhibited transpiration rate in zucchini yellow mosaic virus-infected leaves (Radwan et al., 2006) and on reversal of ABA-induced stomatal closure by phenolic compounds including SA (Rai et al., 1986), which might be accounted for by the SA-reversed stomatal closure (Rai et al., 1986). Furthermore, SA mitigated the $\mathrm{Cd}$-induced decline in activities of antioxidant enzymes (CAT and POD) of roots (Figure $5 \mathrm{~B}$ and $\mathrm{C}$ ), and further increased the levels of GSH and NPT both in roots and in shoots (Figure 6A-D). Hence, SA pretreatment alleviated $\mathrm{Cd}$-induced oxidative stress as evidenced by decrease in concentrations of MDA, an end product of lipid peroxidation (Figure 4B).

It has been recognized that $\mathrm{SA}$ acts as a signaling molecule in regulating $\mathrm{H}_{2} \mathrm{O}_{2}$ levels associated with $\mathrm{H}_{2} \mathrm{O}_{2}$-metabolizing enzymes (Chen et al., 1993). In the present study, pretreatment with SA specifically inhibited CAT activity (Figure $5 \mathrm{C}$ ) and increased $\mathrm{H}_{2} \mathrm{O}_{2}$ level (Figure 4A) in the roots before $\mathrm{Cd}$ exposure as the mode during plant-pathogen interactions (Chen et al., 1993). Although high concentrations of $\mathrm{H}_{2} \mathrm{O}_{2}$ 
can cause irreversible damage and cell death, it can also influence signaling and gene expression in response to environmental stresses, such as chilling (Prasad et al., 1994; Prasad, 1996) and heat shock (Davletova et al., 2005). In the present study, it seems to suggest that SA-induced $\mathrm{H}_{2} \mathrm{O}_{2}$ "set up" the rice plant to respond to $\mathrm{Cd}$-induced oxidative damage more effectively. For example, the SAinduced $\mathrm{H}_{2} \mathrm{O}_{2}$ was associated with the stimulation of levels of GSH and NPT in rice roots (Figure 6A and $\mathrm{C}$ ) before $\mathrm{Cd}$ exposure, which prepared the rice plant better in the detoxification of $\mathrm{Cd}$ by chelation. Hence, pretreatment with SA suppressed the $\mathrm{Cd}$-induced oxidative damage and strengthened the $\mathrm{Cd}$ tolerance of rice. The SA-increased GSH was also found in Thlaspi goesingense by activation of serine acetyltransferase (SAT), an enzyme related closely to the synthesis of GSH, and enhanced $\mathrm{Ni}$ tolerance in this species (Freeman et al., 2005).

In conclusion, the results from this study using a split-root system show that cadmium can be partly transferred from Cd-exposed roots to Cd-unexposed roots and that cell death can be accelerated in the Cd-stressed roots in response to $\mathrm{Cd}$ stress. The SA-enhanced $\mathrm{Cd}$ tolerance in rice can be attributed to SA-elevated enzymatic and nonenzymatic antioxidants, NPT and SA-regulated Cd uptake, transport and distribution in plant organs. SA might influence $\mathrm{H}_{2} \mathrm{O}_{2}$ signaling pathways in plant defense against various forms of abiotic stress, which should be further investigated to dissect the complicated network of SA and its involvement in plant defense at a molecular level.

\section{Acknowledgments}

The study is jointly supported by the grants from Changjiang Scholars Programme from Ministry of Education of China granted to Y.L., Ministry of Science and Technology (2006BAD02A15) and National Natural Science Foundation of China (Approved no. 30170536). It is also financed by the International Partnership Program of the Chinese Academy of Sciences. We are grateful to Dr. F.J. Zhao of Agriculture and Environment Division, Rothamsted Research, UK, for his constructive comments on this manuscript and to Professor Andrew Smith for help with English.

\section{References}

Aebi H. Catalase in vitro. Method Enzymol 1984;105: 121-6.
Beffa R, Martin HV, Pilet PE. In vitro oxidation of indoleacetic acid by soluble auxin-oxidase and peroxidases from maize roots. Plant Physiol 1990;94: 485-91.

Bradford MM. A rapid and sensitive method for the quantitation of microgram quantities of protein utilizing the principle of protein-dye binding. Anal Biochem 1976;72:248-54.

Brennan T, Frenkel C. Involvement of hydrogen peroxide in the regulation of senescence in pear. Plant Physiol 1977;59:411-6.

Brisson LF, Tenhaken R, Lamb C. Functions of oxidative cross-linking of cell wall structural proteins in plant disease resistance. Plant Cell 1994;6:1703-12.

Chardonnens AN, ten Bookum WM, Vellinga S, Schat $\mathrm{H}$, Verkleij JAC, Ernst WHO. Allocation patterns of zinc and cadmium in heavy metal tolerant and sensitive Silene vulgaris. J Plant Physiol 1999;155:778-87.

Chen Z, Silva H, Klessig DF. Active oxygen species in the induction of plant systematic acquired resistance by salicylic acid. Science 1993;262:1883-6.

Cosio C, DeSantis L, Frey B, Diallo S, Keller C. Distribution of cadmium in leaves of Thlaspi caerulescens. J Exp Bot 2005;56:765-75.

Costa G, Morel JL. Cadmium uptake by Lupinus albus (L.): Cd excretion, a possible mechanism of Cd tolerance. J Plant Nutr 1983;16:1921-9.

Davletova S, Rizhsky L, Liang HJ, Zhong SQ, Oliver DJ, Coutu J, et al. Cytosolic ascorbate peroxidase 1 is a central component of the reactive oxygen gene network of Arabidopsis. Plant Cell 2005;17: 268-81.

Drazic G, Mihailovic N. Modification of cadmium toxicity in soybean seedlings by salicylic acid. Plant Sci 2005; 168:511-7.

Drew MC, He CJ, Morgan PW. Programmed cell death and aerenchyma formation in roots. Trends Plant Sci 2000;5:123-7.

Durner J, Shah J, Klessig DF. Salicylic acid and disease resistance in plants. Trends Plant Sci 1997;2:266-74.

Fojtová $M$, Kovařík A. Genotoxic effect of cadmium is associated with apoptotic changes in tobacco cells. Plant Cell Environ 2000;23:531-7.

Foreman J, Demidchik V, Bothwell JHF, Mylona P, Miedema $\mathrm{H}$, Torres MA, et al. Reactive oxygen species produced by NADPH oxidase regulate plant cell growth. Nature 2003;422:442-6.

Freeman JL, Garcia D, Kim D, Hopf A, Salt DE. Constitutively elevated salicylic acid signals glutathione-mediated nickel tolerance in Thlaspi nickel hyperaccumulators. Plant Physiol 2005;137: 1082-91.

Giannopolitis CN, Ries SK. Superoxide dismutase in higher plants. Plant Physiol 1977;59:309-14.

Greenberg JT. Programmed cell death: a way of life for plants. Proc Natl Acad Sci USA 1996;93:12094-7.

Guo B, Liang YC, Zhu YG, Zhao FJ. Role of salicylic acid in alleviating oxidative damage in rice roots (Oryza sativa) subjected to cadmium stress. Environ Pollut 2007a;147:743-9. 
Guo B, Liang YC, Li ZJ, Guo W. Role of salicylic acid in alleviating cadmium toxicity in rice roots. J Plant Nutr 2007b;30:427-39.

Heath RL, Packer L. Photoperoxidation in isolated chloroplast. I. Kinetics and stoichiometry of fatty acid peroxidation. Arch Biochem Biophys 1968;25:189-98.

Hissin PJ, Hilf R. A fluorometric method for determination of oxidized and reduced glutathione in tissues. Anal Biochem 1976;74:214-26.

Lee S, Petros D, Moon JS, Ko TS, Goldsbrough PB, Korban SS. Higher levels of ectopic expression of Arabidopsis phytochelatin synthase do not lead to increased cadmium tolerance and accumulation. Plant Physiol Biochem 2003;41:903-10.

Liao YC, Chang Chien SW, Wang MC, Shen Y, Hung PL, Das B. Effect of transpiration on $\mathrm{Pb}$ uptake by lettuce and on water soluble low molecular weight organic acids in rhizosphere. Chemosphere 2006;65:343-51.

Marschner $\mathrm{H}$. Mineral nutrition of higher plants. Part 3. Long distance transport in the xylem and its regulation. London: Academic Press; 1995. pp. 112-115.

Metwally A, Finkemeier I, Georgi M, Dietz KJ. Salicylic acid alleviates the cadmium toxicity in barley seedlings. Plant Physiol 2003;132:272-81.

Mittler R, Vanderauwera S, Gollery M, Van Breusegem F. Reactive oxygen gene network of plants. Trends Plant Sci 2004;9:490-6.

Novák V, Vidovič J. Transpiration and nutrient uptake dynamics in maize (Zea mays L.). Ecol Model 2003; 166:99-107.

Page V, Feller U. Selective transport of zinc, manganese, nickel, cobalt and cadmium in the root system and transfer to the leaves in young wheat plants. Ann Bot 2005;96:425-34.

Papoyan A, Kochian LV. Identification of Thlaspi caerulescens genes that may be involved in heavy metal hyperaccumulation and tolerance. Characterization of a novel heavy metal transporting ATPase. Plant Physiol 2004;136:3814-23.

Perfus-Barbeoch L, Leonhardt N, Vavasseur A, Forestier C. Heavy metal toxicity: cadmium permeates through calcium channels and disturbs the plant water status. Plant J 2002;32:539-48.

Pietrini F, lannelli MA, Pasqualini S, Massacci A. Interaction of cadmium with glutathione and photosynthesis in developing leaves and chloroplasts of Phragmites australis (Cav.) Trin. ex Steudel. Plant Physiol 2003; 133:829-37.

Prasad TK. Mechanisms of chilling-induced oxidative stress injury and tolerance in developing maize seedlings: changes in antioxidant system, oxidation of proteins and lipids, and protease activities. Plant J 1996;10:1017-26.

Prasad TK, Anderson MD, Martin BA, Stewart CR. Evidence for chilling-induced oxidative stress in maize seedlings and a regulatory role for hydrogen peroxide. Plant Cell 1994;6:65-74.

Radwan DEM, Fayez AK, Mahmoud SY, Hamad A, Lu GQ. Salicylic acid alleviates growth inhibition and oxidative stress caused by zucchini yellow mosaic virus infection in Cucurbita pepo leaves. Physiol Mol Plant Pathol 2006;69:172-81.

Rai VK, Sharma SS, Sharma S. Reversal of ABA-induced stomatal closure by phenolic compounds. J Exp Bot 1986;37:129-34.

Salt DE, Prince RC, Pickering IJ, Raskin I. Mechanisms of cadmium mobility and accumulation in Indian mustard. Plant Physiol 1995;109:1427-33.

Schützendübel A, Polle A. Plant responses to abiotic stresses: heavy metal-induced oxidative stress and protection by mycorrhization. J Exp Bot 2002;53: 1351-65.

Schützendübel A, Schwanz P, Teichmann T, Gross K, Langenfeld-Heyser R, Godbold DL, et al. Cadmiuminduced changes in antioxidative systems, hydrogen peroxide content, and differentiation in scots pine roots. Plant Physiol 2001;127:887-98.

Schützendübel A, Nikolova P, Rudolf $C$, Polle A. Cadmium and $\mathrm{H}_{2} \mathrm{O}_{2}$-induced oxidative stress in Populus $\times$ canescens roots. Plant Physiol Biochem 2002;40: 577-84.

Tani FH, Barrington S. Zinc and copper uptake by plants under two transpiration rates. Part I. Wheat (Triticum aestivum L.). Environ Pollut 2005;138:538-47.

Welch RM. Micronutrient nutrition of plants. Crit Rev Plant Sci 1995;14:49-82.

Welch RM, Hart JJ, Norvell WA, Sullivan LA, Kochian LV. Effect of nutrient solution zinc activity on net uptake, translocation, and root export of cadmium and zinc by separated sections of intact durum wheat (Triticum turgidum L. var durum) seedlings roots. Plant Soil 1999;208:243-50. 